\title{
Privatizing subjectivities: how New Public Management (NPM) is designing a "new" professional in education
}

\author{
Privatizando subjetividades: como a Nova Gestão Pública (NGP) está criando o \\ "novo" profissional da educação \\ Privatizando subjetividades: como la Nueva Gestión Pública (NGP) está \\ creando el "nuevo" profesional de la educación
}

GARY ANDERSON

Resumo: Este estudo apresenta uma análise crítica de como o ensino e a gestão vem sendo rearticulada pelas políticas neoliberais e pelas práticas da nova gestão política. Analisa essas mudanças nos setores sociais e compara com políticas internacionais. Essas novas organizações flexíveis fazem parte de um crescente modelo de negócios neoliberal que alguns teóricos sociais atribuem uma inautenticidade crescente nas organizações (Sennett, 1998), desenvolvem maior flexibilidade para responder aos mercados e não para satisfazer as necessidades humanas daqueles que trabalham neles. O estudo concluiu que o modelo concorrencial de gestão escolar não está mudando apenas o que os profissionais fazem, mas sim quem eles são. A concorrência está reconstruindo suas próprias identidades, tanto pessoais como profissionais.

Palavras-chave: Políticas Públicas Educacionais; Nova Gestão Pública; meritocracia

Abstract: This study presents a critical analysis of how education and management have been re-articulated by neoliberal policies and practices of new political management. It analyzes these changes in the social sectors and compares them with international policies. These new flexible organizations are part of a growing model of neoliberal business to which some social theorists attribute a growing inauthenticity in organizations (Sennett, 1998), and a development of greater flexibility to respond to the markets and not to satisfy the human needs of those who work in these markets. The study concluded that the competitive model of school management is not only changing what professionals do but who they are. Competition is rebuilding their own identities, both personal and professional.

Keywords: public educational policies; New Public Management; meritocracy.

Resumen: Este estudio presenta un análisis crítico de cómo la enseñanza y la gestión están siendo (re)articuladas por las políticas neoliberales y por las prácticas de la nueva gestión política. Analiza esos cambios en los sectores sociales y compara con políticas internacionales. Esas nuevas organizaciones flexibles forman parte de un creciente modelo de negocios neoliberales que algunos teóricos sociales atribuyen una inautenticidad creciente en las organizaciones (Sennett, 1998), desarrollan mayor flexibilidad para responder a los mercados 
y no para satisfacer las necesidades humanas de aquellos que trabajan en ellos. El estudio concluyó que el modelo de la concurrencia de gestión escolar no está cambiando solo lo que hacen los profesionales, sino quienes son ellos. La concurrencia está reconstruyendo sus propias identidades, tanto personales como profesionales.

Palabras clave: Políticas Públicas Educativas; Nueva Gestión Pública; meritocracia.

\section{INTRODUCTION}

In 2008, the New York City Department of Education mandated that every school have an inquiry group (Robinson, 2010). In theory, anyone who believes that teachers should engage in collaborative inquiry and be provided with lots of student data should support this policy, although some might object to its being mandated. However, when the focus is almost exclusively on testing data or other quantitative outcomes, such policies can have problematic outcomes. An account by a teacher in New York City is typical of anecdotes widely shared by teachers who are frustrated at how tightly scaffolded (Talbert, 2012) and protocoled (McDonald, 2007) these inquiry groups tend to be. In too many cases, while claiming to empower teachers and principals with data, they are actually deprofessionalizing them.

The teacher reported that the inquiry group in her school observed that their most pressing problem was that an alarming number of their students were dropping out between ninth and tenth grade. They decided to select fifteen ninth graders and do interviews and focus groups with them. Their goal was to better understand the issues they were facing and to see if some of them might be school or classroom-related and therefore amenable to intervention by the school.

When the data coach from the central office attended their next inquiry group meeting, they were told that they did not seem to understand how the inquiry group was supposed to work. They were to use testing data to identify deficits in their students' achievement and to provide remediation. This meant using spreadsheets of student test scores to identify which skills needed reteaching. The teachers felt that their own approach to school inquiry was not valued and began to feel that the inquiry groups were not meant to be about authentic inquiry at all. Rather, they suspected that they were put in place, at least in part, as a way to get teachers to use the quantitative data that the district was generating through their contracts with data gathering, warehousing, and management firms. They felt that these "inquiry groups" were in fact, more about data - and a certain type of data — than any kind of authentic inquiry. 
A typical data-driven approach was that of SAM (Scaffolded Apprenticeship Model) which "engages a team of teachers in systematically using evidence of struggling students' skill gaps to both design instructional responses and re-design systems that inhibit their skill development" (Talbert, 2012, p. 5). Of course, "skill gaps" in too many cases, refer to spreadsheets of test data; not teacher generated formative assessments.

Some have argued that this attention to individual student data encourages a meritocratic view of schooling and undercuts a more complex understanding of socio-cultural, socio-emotional, and out-of-school factors that impact children (Berliner, 2009). On a more pragmatic level, teachers complain that there is too much lag time between the test and when they get the data. Furthermore, it reduces teaching and learning to a process of test-remediate, test-remediate, test-remediate which impoverishes teaching and provides little professional development or judgment for teachers.

In fairness, some forethought and structure do need to be in place for a successful collaborative inquiry to occur in schools. Moreover, some principals were able to use the mandated spaces the inquiry groups provided to promote and support authentic inquiry, and many data coaches had a more expansive notion of inquiry and teaching. Nevertheless, the issue from the district's perspective was one of getting a "buy-in" from teachers to use the 80-million-dollar Achievement Reporting and Innovation System (ARIS) database that the New York City Department of education had purchased (and is now defunct) (Phillips, 2015). While the new district superintendent brings a somewhat different philosophy regarding the use of data, the damage to the teaching profession and the creation of a narrow culture of data utilization will be hard to reverse.

There are many more examples of how teachers and principals feel that they are not involved in decisions that affect their professional lives and how their professional judgment is disrespected and their work degraded in a growing "audit" culture. At the end of this article, I will provide an example of what collaborative teacher inquiry can look like when teachers are involved in decisionmaking and their professional judgment drives the inquiry.

Meanwhile, there is a growing body of research that documents a major shift in what it means to be a professional (Evetts, 2011; Fenwick, 2016). This shift is occurring in both the private and public sector. Because public education is influenced by trends within the private sector, we will discuss how private sector workers are experiencing the neoliberal workplace. Then we will discuss how this is affecting public sector professionals, specifically teachers and administrators. We will also discuss in some detail how shifts in the political economy and the policy context have led to a tendency toward deprofessionalization. 


\section{THE POLITICAL AND ECONOMIC CONTEXT FOR THE CONSTRUCTION OF A "NEW" PROFESSIONAL}

In this article, I will engage in a critical analysis of the ways teaching and leading are being reengineered by Neoliberal policies and the New Public Management practices. In order to critically analyze these changes in policy and practice, I will work across social sectors (education, business, public health, criminal justice, etc.) and compare policies internationally.

Unfortunately, most scholarship in education are produced within narrow disciplinary and sectorial "silos" and are country specific in their research focus, even though school reform is now a global phenomenon. And this is not only true in the field of education. Researchers across fields are so specialized that they cannot possibly understand the proverbial elephant, but only the trunk, a leg, or the tail. And yet, what is happening to educators today is also happening to nurses, social workers, doctors and police officers. And these changes are occurring on every continent.

A "new professionalism" (Evetts, 2009; 2011) is being constructed in all professions and in all countries. While it is enacted differently depending on local contexts, the struggles and dilemmas of the British, Chilean, Australian, and U.S. teachers, principals, and professors are strikingly similar, as are the neoliberal policies these countries have implemented since the 1980s. A few countries have taken a different route. Finland is probably the best known. In there, the government invests heavily in education, teachers are still highly professionalized, and they see teaching as a long-term career and their professional judgment is respected (Adamson, Astrand and Darling-Hammond, 2016; Salhberg, 2015). In Finland, there are no standardized tests, charter schools, vouchers, or any other market policies that some countries use instead of following a public investment strategy. And yet, Finland scores among the very top nations in the world in educational achievement.

Returning to Max Webber's classic distinction between instrumental and substantive rationality might help us frame this neoliberal shift, at least at the organizational level. Much new policy language contrasts "old" bureaucracy with new entrepreneurial approaches that claim to have flattened hierarchies and de-bureaucratized organizations. Many still tend to blame public bureaucracies for problems in education, and the critique of bureaucracy is embedded today in coded language like "educrats." Max Webber focused heavily on the threat that the instrumental rationality of bureaucracies represented for society. In such organizations, people tend to be means to ends, rather than ends in themselves, he argued. Human relations theories tend to call for treating people well and 
including them in decisions, not so much because this is the way people should be treated, but rather, because "empowered" employees tend to be more productive.

Webber sought more substantive forms of rationality in which people were ends in themselves and in which social ends took precedent over individual goals. Newer "network" organizations have changed in form, but as we will see, they continue to operate on the basis of instrumental rationality, a tendency exacerbated in public organizations as they increasingly operate in a marketized environment.

While new business models attempt to manage through network organization, rather than through bureaucratic hierarchies, there is some evidence that this has intensified instrumental rationality, not reduced it. These new flexible organizations are part of a growing neoliberal business model to which some social theorists attribute a growing inauthenticity in organizations (Sennett, 1998). They have developed greater flexibility to respond to markets, not to meet the human needs of those who work in them.

As market relations become dominant in all aspects of our lives, it becomes increasingly difficult to think beyond individual competition towards any sense of a common good. While most people think of neoliberalism as a purely economic model, it has important social and cultural consequences that we are only beginning to understand. Richard Sennett (2006) provides perhaps the most eloquent account of the ways that shifts in political economy have resulted in cultural shifts in our workplaces and in the ways we live our lives. Since the corporate workplace is increasingly the model for schools, Sennett's work has important implications for 21 st century school leaders. In his qualitative study of several corporations, Sennett has identified characteristics of work in what he calls the new capitalism. I will provide a condensed version of his argument here.

Sennett (2006) traces the recent phenomenon of globalization back to the breakdown in 1973 of the Bretton Woods controls over the global circulation of money. After Bretton Woods, there were large amounts of new capital seeking short-term investments. Later, stock prices began to replace profit as a goal for many businesses. Money was made, not by owning and producing, but by trading, and later speculation. This new speculative and flexible approach to capital has changed work life and institutional structures, particularly in sectors of capitalism such as finance, insurance, real estate, media, communications and high technology, where short-term exchange replaces long-term relationships. To fit into this new "fast" capitalism, workers have to give up notions of stability of employment and become flexible, mobile, workers in a constantly changing global economy. 
Furthermore, workers become disposable as capital continuously seeks to cut labor costs though automation and outsourcing. Neo-liberal management books of the 1990s like the best seller, Who Moved My Cheese? use a childlike allegory about mice who embrace change to prepare the ideological terrain for the new entrepreneurial worker. The lesson is that it is better to see losing one's job as an opportunity for some better entrepreneurial opportunity that surely lies around the corner. The new entrepreneurial culture that is promoted in all sectors of society prepares employees for this new world of unstable employment in the new "risk" society (Beck, 1992). Along with this new instability of work comes intensification of work leading to longer work hours and greater levels of stress and anxiety.

However, Sennett (1998) argues that such trends are actually counterproductive for business, since the cost to business of the resulting short-term employment is that it reduces employee loyalty and organizational memory. Moreover, with shorter contracts, work in teams, and a highly competitive internal work environment, authentic relationships are less likely to form because of short timelines. This continuous employee turnover and the tendency to use temporary workers and outside consultants weaken institutional knowledge. He argues that these new tendencies are good for the bottom line and stock prices, but are not good for the long-term health of businesses, national productivity, or the building of relationships and personal character. In fact, he titled one book in his recent trilogy, The Corrosion of Character: The Personal Consequences of work in the New Capitalism.

The creation of authentic human ties cannot easily occur in transient workplaces and communities. As principals in schools are moved from school to school and teacher turnover, especially in urban districts grows, a similar phenomenon occurs in education. Flexible organizations in a choice environment means teachers, administrators, and students will be more mobile, leading to less stability and a weakening of organizational learning. New, younger teachers may tolerate increased intensification and standardization of work, but many experienced teachers with families and a strong professional culture are tending to change careers or retire early. The very notion of teaching or administration as a life-long career is becoming a thing of the past. In the long run, this will have devastating effects on the quality of schooling.

Sennett (2006) also identifies other personal deficits associated with this new neoliberal culture. The first is the demise of the work ethic. Only a fool would delay gratification in the new flexible workplace. Employees report feeling a sense of personal betrayal as companies trade loyalty to workers for short-term profits. While some "bootcamp" charter schools may harness the idealism of elite 
twenty-somethings for a time, eventually, they burn out and move on to more lucrative careers. Second, this loss of long-term employment with its associated benefits and pensions make it more difficult for newer generations of employees to create life narratives. While much Welfare State employment was not exciting, it provided people with a life narrative in which they could pay a mortgage over 30 years, look forward to a pension and social security, and plan for vacations. There is an absence of any way to think strategically about one's life, one's sense of purpose, future goals, and economic security.

In flattened hierarchies or network organizations, pyramidal hierarchy is replaced by a horizontal elite core and a mass periphery with minimal mediation and communication between the two. It represents a new concentration of power without centralization of authority. According to Sennett (1998), "this absence of authority frees those in control to shift, adapt, reorganize without having to justify themselves or their acts. In other words, it permits the freedom of the moment, a focus just on the present. Change is the responsible agent; change is not a person" (Sennett, 1998, p. 115).

Internal units are created to compete with each other for contracts. Outside consultants are brought in to do the dirty work that management used to do. Senior management can claim they are taking their cue from the expert consultants who come in and leave quickly. In this impersonal environment, no relationships are built, as no one has to take responsibility for decisions. Upper management with its stronger networks moves more often as new opportunities arise. Personnel records take the place of humans who are being standardized so "performance" can be compared (just as high stakes testing in education allows students, teachers, and schools to be compared as a prerequisite for a marketized system). Flexibility to adjust to changes in the market is gained. This is perhaps good news for stockholders seeking short term profits, upper level executives and consultancy firms, but it isn't clear who else benefits, or what it contributes to the common good. It also, according to Sennett, makes long term, authentic relationships less likely.

This new model is being intentionally implemented in school districts across the country. In New York City, under Mayor Bloomberg, a corporate model was implemented. Upper-level public administrators contracted out to private companies or took private sector positions in the burgeoning education services industry. Principals had a "choice" of vendors and networks. Publicprivate partnerships were the vehicle and discourse for this shift in work culture. This restructuring of the institutional environment dramatically changed the work culture of schools. While it is true that some professionals thrive in such environments, most principals in New York City reported being more beleaguered 
than empowered (Shipps, 2012). If Sennett's analysis of the new corporate culture is any indication, in education, we can expect to see less employee loyalty, more work stress, and a performance culture.

\section{BILL GATES: "IT IS ASTONISHING WHAT GREAT TEACHERS CAN DO FOR THEIR STUDENTS”}

Unlike Finland, The U.S. has chosen an approach to education that does not emphasize public investment, but rather the market-based, incentivist policies and high stakes outcomes measures (Adamson, Astrand \& DarlingHammond, 2016). This approach aligns with neoliberal's anti-government and anti-union ideology. While investment in education had remained relatively stable prior to 2008 (Baker, 2017), since the recession of 2008, policies of austerity and disinvestment in the U.S. have hit public schools and teachers hard. Since schools are largely financed in the U.S. at the state and local levels, some states and communities have been hit harder than others. With less public investment, public schools are becoming increasingly overcrowded and under resourced as teachers work harder for less pay and larger class sizes. It also leads to more parents abandoning public schools for other options, including a new breed of "prestige charter schools" designed for more privileged parents (Brown \& Makris, 2017). This, added to an already unequal system based on property taxes, is leading to further social stratification and racial segregation.

Weare also becoming increasingly aware that these neoliberal policies of disinvestment by the State are heavily influenced by new policy networks of venture philanthropists, thinktanks, foundations, international agencies and edubusinesses, which are themselves global (Ball, 2012; Fang, 2017; Verger, Lubienski \& Steiner-Khamsi, 2016).As public schools are increasingly absorbed into a market, profit, and efficiency logic, theprofessional identities of teachers and leaders are being redesigned around the vision of these policyentrepreneurs, few of whom are educators or steeped in education policy research (Ball, 2001; Gillies, 2011).

These think tanks, venture philanthropists, and media outlets flood the public with misinformation and "fake" news and documentaries about education. Venture philanthropist, Bill Gates (2011) proclaimed in the Washington Post,

Over the past four decades, the per-student cost of running our K-12 schools has more than doubled, while our student achievement has remained virtually flat. Meanwhile, other countries have raced ahead (Bill Gates, 2011.) 
Even though experts on school finance have debunked this claim, they typically don't have access to the opinion page of the Washington Post (see Baker, 2017). On the other hand, Gates (2011) promotes teacher development as the solution, arguing that,

\footnotetext{
We know that of all the variables under a school's control, the single most decisive factor in student achievement is excellent teaching. It is astonishing what great teachers can do for their students. (Bill Gates, 2011)
}

While educators would not disagree with this, it is ultimately an argument for social disinvestment, since it expects teachers to make up for other social factors that require social investment.

During the 1960 and 1970s there was greater social investment in children and families and a more equitable distribution of society's resources. "Equal Educational Opportunity" was the slogan of the day and the title of the Coleman Report (Coleman, Campbell, Hobson and McPartland,1966), the largest federally funded study of education. During the George W. Bush administration, this languageof equal opportunity was changed in all federal documents, to "narrowing the achievement gap". This was largely a ploy to shift the emphasis from education inputs (resources) to education outputs (test results) (Crawford, 2007).

Ironically, Barton \& Coley (2010) have documented in "The Black-White Achievement Gap: When Progress Stopped", that "from the early 1970s until the late 1980s, a very large narrowing of the gap occurred in both reading and mathematics, with the size of the reduction depending on the subject and age group examined" (Barton \& Coley , 2010, p. 7). They go on to assert that "during the 1990s, the gap narrowing generally halted, and actually began to increase in some cases.” (Barton \& Coley , 2010, p. 7). So, while Gates' call for a focus on developing great teachers is a useful discursive device, it is often used by policymakers to transfer the failure of the State onto teachers, and these new policy entrepreneurs are brilliant at discursively framing their neoliberal policy goals (Lakoff, 2008).

Moreover, these new global policy networks are largely bipartisan, implemented in England by the Tories and Labour, in the U.S. by both Republicans and Democrats, and in Chile by theChristian Democrats and the Concertación (an alliance of left parties). Apple (2001) provides auseful overview of what he calls a "hegemonic alliance of the New Right" including 1) neoliberals, 2) socialconservatives, 3) religious conservatives and a 4) new professional middle class. This is also more or less the alliance that elected Donald Trump. 
Apple's (2001) notion of alliances is useful inthat even though these groups may differ in some areas ideologically and politically, they form a sortof informal coalition pushing for markets, standardization, a reversal of separation of church andstate, and a perpetuation of inequality based on notions of individualism and meritocracy, largely because of the influence of these bipartisan policy networks, a long list of reforms hasbeen implemented globally in the last three decades. They include high-stakes testing, school choice,vouchers (or tuition tax credits) in some cities and states, charter schools (or their equivalent in other countries), principal "autonomy," alternative and fast trackpathways to careers in teaching and leading, privatization and contracting out of public services, mayoralcontrol, data-driven management, public-private partnerships, increased school policing andsurveillance, schools and districts as profit-centers for "vendors", and the forprofit organization of learning through virtual schools and online instruction.

In fact, most of these reforms are not being adopted in middle class and affluent communities, but are largely targeting low-income communities of color (Scott, 2011). While school choice polices and the privatization of urban public schools is promoted by many reformers asthe civil rights issue of our time, some research is finding that public schools actually out-perform private and charter schools when socio-economic level is controlled for (Lubienski\&Lubienski,2014; Mizala \& Romaguera, 1998).

In education, these changes have had a dramatic impact on what it means to be a teacher and leader, particularly in districts that serve low-income students. New advocacy networks fundedby venture philanthropists seek the demise of university-based teacher education and the productionof "new professionals" who are trained to work in the highly scripted, franchised charter and virtualschools of the future (Mungal, 2016; Zeichner \& Pena-Sandoval, 2015).

\footnotetext{
"Warm Body" Laws and the De-professionalization of Teachers.

Known as the "warm body" law, Arizona Senate Bill 1042 signed into law in May, 2017 by Republican Governor Doug Ducey, permits "persons" with a college degree to bypass Arizona's regular teacher certification process to obtain grades 6-12 teaching certificates. They should have 5 years of relevant experience, but "relevant experience" was not defined. In Arizona, charter school "teachers" were already exempt from state certification requirements. Since 2009, the Arizona Legislature has cut school district capital funding by $85 \%$ while it has increased charter school funds for capital purchases and facilities by $15 \%$.
} 


\section{A NEW REGIME OF GOVERNANCE: TRANSFERRING CORPORATE MANAGEMENT PRINCIPALS TO THE PUBLIC SCHOOLS}

How the governance of organizations in the public sector has been transformed by networks of "reformers" is the subject of New Public Management, sometimes referred to as new managerialism or neo-Taylorism (Au, 2011; Trujillo, 2014). Of course, public organizations have always been managed, but in the last four decades there has been a shift from a rule-governed, administrative, bureaucratic management regime to a market and outcomes-based, corporate management regime borrowed from the business world ${ }^{1}$. The following are the most common ideas and practices transferred from the corporate sector (Hood, 1991; Bottery, 1996; Ward, 2011):

- The introduction of markets and quasi-markets within and between public organizations (e.g. schools)

- Closing low-performing organizations and creating "start ups" that are often outside of local democratic control (e.g., charter schools)

- An emphasis on explicit standards and measures of performance

- Greater emphasis on outcomes and their measurement using quantitative data

- Greater use of standardization and "scaling up" of practices

- Contracting out public services to vendors in the private sector and the increased use of consulting companies

- The public sector as an emerging profit center

- A trend toward temporary and short-term workers and against unionization

- Administrative decentralization and bounded autonomy

- Greater discipline and parsimony in resource use in a context of austerity and disinvestment

Most educators have experienced these practices in their daily professional lives. More veteran educators may remember a time before these practices were dominant. Moreover, not all states or school districts have adopted these policies, although NCLB and Race to the Top forced most states to do adopt many of them. In reality, a single governance regime is seldom in place in any state or

1 The previous bureaucratic form of organizing and managing schools was also borrowed from industrial business leaders who propagated organizing efficient schools around the factory model. However, as professional organizations, they contained-in theory, at least-- a strong professional and public ethos. 
district. It is more likely that teachers and leaders experience a mix of different regimes. Therefore, we provide a brief overview of the previous management regime and those that are competing for dominance.

The corporate regime described above is seldom implemented in an ideal fashion. Michael Bloomberg and his chancellor, Joel Klein, attempted to do so during his 12 years as mayor of New York City and New Orleans attempted to do so after Hurricane Katrina. Other cities, such as Chicago, Philadelphia, Washington D.C., Denver, and Detroit also implemented a market regime to some extent. Most of these cities have experienced a great deal of resistance from community organizations and teachers unions, including a national parent-led, opt out of testing movement.

The review in Table 1, presented in the forwarding pages of the four principal governance regimes that are in competition is borrowed from Shipps' (2012) study of New York City principals under former mayor Bloomberg's Market regime. However, as Shipps argues, there are variations within the market regime, and some may exhibit some aspects more than others. She identifies three variations of the Market Regime.

The first is the corporate variation, which borrows notions of statistical control of product quality from the corporate sector. The premise is that corporate practices of standardized evaluation, curriculum, and services, payfor-performance and other meritocratic policies will lead to greater efficiency and accountability. What makes this approach different from the previous bureaucratic, administrative regime (also a product of corporate influence), is that control is exercised at a distance through outcomes measures as opposed to an internal supervisory model. Control is also exercised through what some call concertive control by shifting "the locus of control from management to the workers themselves, who collaborate to develop the means of their own control" (Barker, 1993, p. 411), typically within narrowly defined limits. The use of outcomes measures also provides indicators consumers can use to choose schools, which brings us to the entrepreneurial variation of the Market Regime.

Entrepreneurialism, which emphasizes competition and client choice, creates conditions in which everyone is either a consumer or a marketer. Schools become autonomous businesses competing for (and selecting or rejecting) clients, which principals competing with each other for students and teachers. The publicschool system is viewed as a "monopoly" and the system is privatized as private vendors (many for-profit) compete for public money. Markets are also employed as accountability systems under the assumption that, like businesses, those that fail to attract sufficient clients should be closed. 
Most school districts, including the New York City, have developed a combination of corporate and entrepreneurial strategies called Diverse Provider Regimes, or sometimes referred to as portfolio districts. As Shipps (2012) notes, this regime "combines the standardized outcomes and internal competition of the Corporate Market Regime with an increasedsupply of schools and client choice adopted from Entrepreneurial Market Regimes" (Shipps, 2012, p. 7). In this way, districts hope to get the benefits of both regimes, but principals often get mixed and sometimes contradictory accountability messages.

As we can see from Table 1, while the Market Regime is dominant in most states and districts that have such policies as high stakes accountability, school choice, andpay-for performance, in some cases other regimes may be dominant or emergent. For instance, in many rural school districts an Administrative Regime may still be dominant, in part because, unlike urban settings in which there are many schooling choices, rural districts often only have a handful of schools. This is also true in many affluent suburbs, where home owners have chosen to buy a home there, in part because of the public schools.

In an Administrative Regime accountability is still largely internal, through supervision, bureaucratic mandates, established norms, credentialing, and a certain level of social trust and public service. The Administrative Regime, which was dominant in the post WW II years, generally had elements of the Professional Regime as well, in the sense that teachers had more professional discretion as leaders buffered them from parents and some bureaucratic mandates. Elements of the Professional regime is also present in the form choosing their own professional development, being involved in hiring, and professional learning communities or leadership teams, although, as noted above, these can be coopted by the Market Regime.

Finally, the Empowerment Regime is one that is responsive to particular interest groups or organized communities. These might be parent or neighborhood organizations seeking community control or social movement unions, such as the Chicago Teachers' Union. There are many interest groups today that are an extension of or funded by those promoting a Market Regime, so an Empowerment Regime means being able to distinguish between grassroots organizations and largely corporate funded and typically anti-union advocacy groups, often referred to as "astroturf" or "grasstops" organizations. This can also be a problem with community organizations and unions as well, as it is not always clear who represents the community or, in the case of unions, the rank and file membership.

Sometimes, responsiveness may be to low-income parents in gentrifying communities, or finding ways to engage them in authentic forms of participation 
in school decision-making. Sometimes it involves taking as asset rather than deficit view of parents and communities and seeing them as experts on their own children (Gonzalez, Moll \&Amanti, 2005; Green, 2015). In the micro-political matrix in chapter five, we described how the empowering leader differs from authoritarian, facilitative, and adversarial leaders.

Table 1: Four Ideal Types of Governing and Their Theoretical Characteristics

\begin{tabular}{|c|c|c|c|c|c|}
\hline Regime & Agenda & $\begin{array}{c}\text { Preferred } \\
\text { Accountability }\end{array}$ & $\begin{array}{c}\text { Essential } \\
\text { Actors }\end{array}$ & $\begin{array}{l}\text { Essential } \\
\text { resources }\end{array}$ & $\begin{array}{c}\text { Essential } \\
\text { relationships }\end{array}$ \\
\hline $\begin{array}{l}\text { Administrative } \\
\text { Regime }\end{array}$ & $\begin{array}{l}\text { Sustain system } \\
\text { by buffering it } \\
\text { from political } \\
\text { interference }\end{array}$ & $\begin{array}{c}\text { Bureaucratic } \\
\text { mandates }\end{array}$ & $\begin{array}{c}\text { Teachers, } \\
\text { Administrators, } \\
\text { school board }\end{array}$ & $\begin{array}{l}\text { Technical routines, } \\
\text { Established norms, } \\
\text { Legitimate training } \\
\text { and credentials, } \\
\text { Educator cohesion, }\end{array}$ & $\begin{array}{c}\text { Solidarity } \\
\text { among } \\
\text { educators and } \\
\text { skepticism } \\
\text { about external } \\
\text { change agents. }\end{array}$ \\
\hline $\begin{array}{l}\text { Professional } \\
\text { Regime }\end{array}$ & $\begin{array}{l}\text { Change the } \\
\text { pedagogy and the } \\
\text { culture of schools }\end{array}$ & $\begin{array}{l}\text { Professional } \\
\text { Discretion }\end{array}$ & $\begin{array}{c}\text { Teachers, } \\
\text { Parents, } \\
\text { Administrators, } \\
\text { Elected officials }\end{array}$ & $\begin{array}{l}\text { Educator } \\
\text { expertise, Parental } \\
\text { commitment, Inter- } \\
\text { group mediation, } \\
\text { Pedagogical } \\
\text { alternatives, } \\
\text { Increased } \\
\text { government } \\
\text { funding. }\end{array}$ & $\begin{array}{l}\text { Trust between } \\
\text { parents and } \\
\text { educators } \\
\text { across class, } \\
\text { race, and } \\
\text { ethnic lines. }\end{array}$ \\
\hline $\begin{array}{l}\text { Empowerment } \\
\text { Regime }\end{array}$ & $\begin{array}{l}\text { Authorize new } \\
\text { decision makers } \\
\text { to enable better } \\
\text { unprecedented } \\
\text { decisions. }\end{array}$ & $\begin{array}{c}\text { Political } \\
\text { responsiveness }\end{array}$ & $\begin{array}{l}\text { New Decision- } \\
\text { makers, } \\
\text { Education } \\
\text { interest groups, } \\
\text { Elected and } \\
\text { appointed } \\
\text { officials. }\end{array}$ & $\begin{array}{l}\text { New governing } \\
\text { institutions. } \\
\text { Cohesive group } \\
\text { representation. } \\
\text { Uncorrupted } \\
\text { leadership, Inter- } \\
\text { group mediation, } \\
\text { Legitimate } \\
\text { governing } \\
\text { alternatives, benefit } \\
\text { redistribution }\end{array}$ & $\begin{array}{l}\text { Pacts by } \\
\text { interest } \\
\text { groups to } \\
\text { share decision } \\
\text { arenas and } \\
\text { decision- } \\
\text { making. }\end{array}$ \\
\hline $\begin{array}{c}\text { Market } \\
\text { Regimes }\end{array}$ & $\begin{array}{l}\text { Restructure } \\
\text { schooling for } \\
\text { efficiency and } \\
\text { accountability } \\
\text { (corporate) or } \\
\text { Restructure } \\
\text { schooling for } \\
\text { competition } \\
\text { and choice } \\
\text { (entrepreneurial) }\end{array}$ & $\begin{array}{l}\text { Performance } \\
\text { of Market } \\
\text { Iniciatives }\end{array}$ & $\begin{array}{c}\text { System } \\
\text { managers, } \\
\text { Business, elites } \\
\text { (corporate) } \\
\text { or System } \\
\text { managers, } \\
\text { Private providers, } \\
\text { Parents } \\
\text { (entrepreneurial) }\end{array}$ & $\begin{array}{l}\text { Engaged market } \\
\text { sector, Revised } \\
\text { regulations, Public } \\
\text { investment in } \\
\text { markets, Consumer } \\
\text { Information, } \\
\text { Legitimate } \\
\text { market actors, } \\
\text { Performance } \\
\text { Incentives } \\
\text { (corporate) or } \\
\text { Private financing } \\
\text { for startups } \\
\text { (entrepreneurial) }\end{array}$ & \\
\hline
\end{tabular}


But these practices have become dominant, not because they are more effective or have been successful at improving our public-school system. From an institutional perspective (Meyer \& Rowan, 2006), one might argue that educators have adopted these principals because they enhance the status of educators. It is better to be called a CEO than a district superintendent. But this doesn't explain how the status of the public sector has become so degraded. Advocates of privatization refer deprecatingly to public schools as "government schools" as if the government isn't-in theory, at least--the expression of our public will.

The viability and popularity of New Public Management and privatization has been prepared discursively. Drawing on Whitfield's (2001) study of the privatization process in Britain, Ball (2007) describes three stages through which the creative destruction of the public sector is accomplished. While this is not a coordinated, linear process, it has the following internal logic. The public sector is destabilized through discourses of derision and constant ridicule to undermine its credibility. This is accompanied by disinvestment from and shifting resources within the public sector. Finally, a process of commodification "reworks forms of service, social relations and public processes into forms that are measurable and thus contractible or marketable (Ball, 2007, p. 24). In this way new markets are created that attract private providers creating whole new arenas of commercial activity for "social entrepreneurs."

It is within the context of broader material and discursive change that the educational institutional terrain is prepared for NPM "reforms." As public institutions like schools and universities become more financially strapped, they need to seek funding from the private sector, in many cases from new philanthropic organizations with privatizing agendas. These patterns are evident in an example Ball (2007) offers from a school principal, "You can't run on your ordinary budget, everyone knows that, so you have to get involved in various initiatives and cater for that, the initiative's priorities, and bend your curriculum and your priorities in order to get hold of that bit of money" (Ball, 2007, p. 23). This principal articulates organizational barriers that are deeply informed by broader NPM discursive shifts. Reformist solutions, such as public-private partnerships that help to breach and re-work key boundaries between the public and private (Robertson, Verger, Mundy \& Menashy, 2014; Verger \& Moschetti, 2016), emerge as preferable only within these broader discursive and institutional contexts of public disinvestment. These shifting discourses create new material demands upon schools, which have increasingly become stabilized as a new normal that organizational leaders must adapt to. In the following section, we describe how these shifts in the governance of educational organizations have changed the role and identities of teachers and administrators. 


\section{THE EMERGENCE OF NEW PROFESSIONALISM}

Evetts (2011) conceptualizes the shift in professionalism as one from emphasizing "notions of partnership, collegiality, discretion and trust to increasing levels of managerialism, bureaucracy, standardization, assessment and performance review" (Evetts, 2011, p. 407). Scholars of new professionalism argue that while there are some continuities from the "old" professionalism, a shift has occurred as professionals are increasingly managed and controlled, a tendency that Evetts (2011) refers to as organizational professionalismor professionalism "from above" (Evetts, 2011, p. 407). She contrasts this with occupational professionalism or professionalism "from within" and documents a shift from professional to managerialist values.

This shift suggests a decrease in professional autonomy and in control over one's profession through the exercise of professional judgment and through professional associations, and an increase in control by managers in work organizations. This control is characterized by rational-legal control, standardized work procedures and practices, and external forms of regulation and accountability measures, or what some have called governing or steering from a distance (Kickert, 1995: Rose, 1993).

Although a discourse of "autonomy" and "empowerment" is sometimes used to promote current education reforms, such autonomy is exceedingly constrained and often part of a strategy of tightening up "loosely coupled systems" (Honig \& Rainey, 2012; Meyer \& Rowan, 2006). In other words, as we will discuss in more detail below, while in older public bureaucracies, teachers could create autonomy (for good or ill) by shutting the classroom door, "postbureaucratic" organizations of today are more tightly coupled as high stakes testing can breach the door and enter the classroom.

These NPM reforms instill greater autonomy and an entrepreneurial ethos in budgeting, contracting, and hiring, while the core elements of instruction and curriculum are steered from the top through standards and testing. Managerial moves to provide greater autonomy for middle managers are often part of a trend toward work intensification. For instance, in New York City, where autonomy and markets were central to Mayor Bloomberg's reforms, school principals reported being more beleaguered than empowered (Shipps, 2012).

This shift from occupational to organizational professionalism may seem more dramatic for some professions, such as physicians, who are increasingly leaving private practice for large hospitals and health organizations. Teachers, on the other hand, have always worked largely within public or private bureaucracies, but the loosely coupled nature of educational systems buffered teachers from more 
direct forms of control, depending chiefly on internal forms of accountability (DiPaola \&Tschannen-Moran, 2005; Weick, 1976). This meant that while the bureaucracy and principals exerted a certain level of hierarchical control, teachers exercised a great deal of autonomy in their classrooms. They were only under direct control when they were being observed by principals or supervisors.

Welch (1998) documents parallels between today's reforms and businessled reforms of the nineteenth and early twentieth century when forms of efficiency were imposed on schooling through the imposition of a business ethos. In his analysis of the British Revised Code of 1860 whose centerpiece was "payment by results," he documents the audit culture of the time, which, like today, resulted in creative compliance. According to Welch,

teachers 'stuffed and almost roasted' their pupils on test items once the teachers knew that the visit of the inspector was imminent. Other teachers secretly trained their pupils so that when they were asked questions they raised their right hands if they knew the correct answer but their left if they did not, thus creating a more favorable impression upon the visiting inspector. (Welch, 1998, p. 161)

Nearly one hundred and fifty years later, such pressures are having a similar effect. The following is from the Columbus dispatch in Columbus, Ohio, but newspapers across the country are full of similar stories.

\footnotetext{
Answer sheets and test booklets arrive at districts in securely taped boxes, shipped by FedEx or UPS. Packets are shrink-wrapped and are supposed to be stored in a locked room until test time. But in some districts, teachers got access last school year. Some made copies. Others shared the questions with students ahead of time, or gave answers during the test. And a few devised nonverbal signals to cue children that their answers were incomplete. For all the lock-and-key procedures and explicit rules, more teachers cheated on Ohio standardized tests than ever before (Smith Richards, 2006, p.4).
}

The difference between these two examples is that in the second one teachers are controlled from a distance and by a faceless inspector, that comes shrink wrapped and delivered by UPS, or today more likely through a computer screen. These forms of control not only bypass the principal and superintendent and flow directly into the classroom, but they also decrease the amount of autonomy teachers and principals have over curriculum and instruction.

Some have argued that principals appear to have benefited by receiving greater autonomy over such things as budgets and hiring, and appear to be reprofessionalizing (Jarl, Fredrikson \& Persson, 2011). But they are encouraged to professionalize around the principles of New Public Management and to do so independent of teachers, which reinforces a management-worker split. 
Furthermore, alternative pathways to the principalship--and teaching as well-have weakened attempts at professionalization through the usual channels of certification and professional associations.

\section{NEW ENTREPRENEURIAL PROFESSIONALS WITHIN AN AUDIT CULTURE}

From policing to teaching to practicing medicine, the shift to New Public Management elaborated above has reconstituted most occupations and professions. In education, a new generation of teachers and administrators are being socialized into a very different workplace with a different conception of teaching and leading. While teachers increasingly teach to the test, leaders are expected to lead to the test. Since control is now exercised through market discipline and high stakes tests that increasingly drive what goes on in classrooms, principals are being given more and more "autonomy," oftentimes to exercise leadership over less and less (Shipps, 2012).

Some see promise in the notion of distributed leadership as a way to build greater professional capacity. But, while workplaces are being redesigned to intensify work and distribute it horizontally, power is being distributed upward by centralizing policy over curriculum and instruction through high stakes testing and mayoral control. According to Evetts (2011), these developments are shifting the locus of control from a previous focus on professional judgment to control through policies that increase organizational professionalism from above and reduce occupational professionalism from within. The new teacher and administrator are put in a position in which they must look to market and test-based forms of accountability for direction rather than their professional instincts, training, associations, or unions. The ability of new digital technologies to integrate management information systems and standardize the labor process promises to intensify this tendency (Burch, 2014; Selwyn, 2011).

Another way of thinking of this that we have moved from an emphasis on internal accountability to external accountability. According to Carnoy, Elmore, and Siskin (2003), internal forms of accountability include,

\footnotetext{
Individual teachers' and administrators' beliefs about teaching and learning, their shared understanding of who their students are, the routines they develop for getting their work done, and the external expectations from parents, communities, and administrative agencies under which they work. (Carnoy, Elmore, and Siskin. 2003, p. 3)
} 
Ironically, this shift in accountability has both narrowed their professional discretion while also expanding and intensifying their role expectations. Summarizing research in changing teacher roles in the U.S., Valli \& Buese (2007) discuss a widening scope of teacher responsibilities, including heightened expectations of collaboration outside the classroom, strict adherence to new curricular and instructional requirements, and the collection and analysis of assessment data.

While these additional role expectations could--and under certain circumstances--have expanded educators' professionalism (Stillman, 2011), it has more often tended to reduce it to working within an audit culture of external metrics that requires being accountable to standards and criteria that they had no part in developing (Apple, 2004; Strathern, 2000). As noted at the beginning of this chapter, even where professional learning communities are in place, the data teachers are encouraged to analyze and the tasks they rehearse are typically not their own. In most cases, conception and execution have been successfully separated (Apple \& Jungck, 1992). This separation mimics proletarianization, in which craft labor was fragmented and replaced by factory wage labor.

The shift to greater external accountability has not only exposed educators to new forms of control through an audit culture and curbs on their professional judgment, but also to a marketized environment that forces them to compete both internally with each other and externally with other organizations. So, professionals, adept at co-existing with bureaucratic forms of control, find themselves in new territory. Freidson (2001) viewed professionalism as a mechanism for organizing some aspects of social life based on expertise and social trust. Professionals depend on this social trust with the public for their legitimacy. In this sense, professionalism both competed with and provided some protection from both market and bureaucratic forms of organization. As professionalism is eroded as a countervailing force to both bureaucracy and markets, social trust and public capacity-building is eroded as well.

The new pressure to compete has created the new entrepreneurial professional, requiring teachers and principals to become more competitive. For instance, the role expectations of today's principals and superintendents have become more entrepreneurial as they are increasingly asked to interface, not only with a district or state bureaucracy, but rather with a series of vendors and consultants selling them everything from professional development services to data warehousing and management (Burch, 2009). 


\section{WHAT'S WRONG WITH PRINCIPALS BEING ENTREPRENEURIAL LEADERS?}

Throughout this article, I have been critical of this shift towards more entrepreneurial and competitive forms of leadership. Yet older, public servant approaches to leadership have also been heavily critiqued as failing to challenge the grammar of schooling and the inequalities public schools have reproduced (Callahan, 1962; Foster, 1986). The premise of public school leadership has generally been to serve and be an advocate for all children, though this has seldom been realized. Soone might rightfully ask how a market-based approach might better serve all children and lead to greater achievement and equitable outcomes.

Before the age of NPM, teachers who aspired to be principals were taught that their central task as an instructional leader was to help a teaching staff improve their instruction, even with a staff composed of teachers ranging from incompetent to outstanding. If the incompetent ones (usually only one or two) could not improve after working with them over time, then the task was to counsel them out of teaching or use documentation to move them out (Bridges, 1992). They were not taught to harass them or scapegoat unions; but rather were taught how to provide due process by helping struggling teachers improve, while documenting their work in case they did not.

They were also taught how to encourage professional renewal for burned out or "plateaued" teachers, how to target professional development for the teachers with specific needs, and how to inspire the good teachers to become outstanding (Milstein, 1990). The dilemma for most principals back then was how to carry out both a management and instructional leadership role given the time constraints (Rallis \& Highsmith, 1986). Gradually, teacher leader positions, literacy coaches, and professional learning communities (PLCs) were added in many schools for additional support for teacher development and instructional support.

Because most teachers saw teaching as a career and stayed in schools longer, there was time to do this kind of capacity building in the school, which also meant transferring this building capacity system-wide if these teachers moved to another school. All children benefited when teachers improved. This was seen as particularly important in low-income schools where students needed skilled teachers and depended on institutional agents, like teachers, counselors and administrators for access to dominant social and cultural capital (StantonSalazar, 2011).

The new entrepreneurial principal, modeled after business CEOs, works in a different social context and brings a different ethos and internal logic to 
the public sector (Ward, 2011). Particularly in urban school districts with school choice policies, there is a tendency for principals to recruit "lower-maintenance" students and teachers to their schools in order to improve test scores. "High maintenance" students, such as those with learning disabilities, limited English or behavior problems require more effort, resources and skilled teachers.

Given the amount of time and effort some principals have to put into marketing their schools in these districts, there is often little time to mentor teachers, they know students with special needs or behavior problems may lower their test scores.

Charter schools are particularly geared for this kind of entrepreneurialism, but even public school principals in districts with school choice are pressured to engage in the same behavior (Lubienski \& Lubienski, 2006). Charter schools tend to have far fewer students with special education or English Language needs (Baker, 2012), leaving public schools to work with more of these students. Some principals have figured out that if they recruit good teachers, their job is easier, their test scores improve and their careers take off. In reality, most principals would rather not play this cynical game, but if competition is the game, then they have to play.

Shipps and White (2009) interviewed principals in New York City. A typical response to the pressures of the accountability was the following:

\begin{abstract}
We aggressively go after teachers...We spend a ton of money andeffort on teacher recruitment, everything from having fancy materials that make our school lookbetter than any other school, and banners... My hiring coordinator, you know, emails every[education] professor... at every major university around the country. (Shipps and White, 2009, p. 368)
\end{abstract}

They found that principals also had strategies for recruiting students to make sure they got the "right kids". Here is one principal's strategy:

I'm a competitive person by nature...soI think by nature you are always looking at where you stand in comparison to those in your community...I study the ones who don't come... [Ours] isn't always their first choice. There are two other choices they [tend to] make...So generally we go through all the applications...I get a thousand applicantsfor seventy-five seats. I'm never in a situation where I go begging for kids, I just need the right kids. (Shipps and White, 2009, p. 368)

Competition is also common within schools. Students are often awarded with T-shirts or vouchers to buy snacks. Teachers compete with each other for the best test scores, which means they mimic principals in trying not to have "more difficult" students assigned to their classes. 
What is troubling about these quotes is not merely that competition is changing what professionals do, but rather who they are. It is reconstructing their very identities, both personal and professional.

But a principal who recruits great teachers to his or her school is not building capacity. Those teachers leave behind a classroom of equally deserving students at their former school. All this does is move resources around the district or between districts with the goal of enhancing a particular school's (and by extension, principal's) performance. Closing, turning around or reconstituting schools does the same thing. It just moves resources around the system on the pretext of getting rid of "bad teachers" (Malen, Croninger, Muncey \& RedmondJones, 2002). The former notion of principals as instructional leaders, helping all teachers improve, increases system capacity. The entrepreneurial model does not.

At least an entrepreneurial business person can argue that her selfinterest in building a successful business allows her to support herself and her family and creates jobs for others. She wants to poach good employees from other companies because they are in competition for customers. This is the nature of a business.

But in public school systems, viewing a school as "my business" or "start up" produces pressures to recruit good teachers from other schools, to reject kids who might lower my test scores, and to market my school to far flung parents. The nature of a public school is to work for the common good of all families and children, not just those in "my school." It is hard to imagine how this can be viewed as serving or being an advocate for all children, and there is no evidence that it pays off in higher achievement levels. In fact, there is evidence that it adds to an already highly stratified and segregated public school system (Frankenberg, Siegel-Hawley \& Wang, 2011).

There is also evidence that a focus on using test scores as a metric for competition has caused school leaders to focus less on non-cognitive skills, eliminating the affective, physical, political and socio-emotional dimension of schooling. Reardon (may, 2013) in discussing a growing social class achievement gap in testing and college attendance, indicates that

A related trend during the last 20 years is the growing social-class gap in other important measures of adolescents" "soft skills" and behaviors related to civic engagement, such as participating in extracurricular activities, sports, and academic clubs; volunteering and participating in community life; and self-reports of social trust (Putnam, Frederick, \& Snellman, 2012).

Of course, it is also true that public schools for poor families and children of color were not very good thirty years ago before a market logic entered 
education. But had districts continued to focus on an ethos of public service professional learning communities, and ultimately more cultural responsive pedagogies, they might have made more progress by now than by using high stakes tests and market logics to "incentivize" and punish teachers and principals. We will never know how much progress we might have made. But we do know that we have lost many outstanding teachers and principals (and perhaps more than a few mediocre ones) because they no longer felt they could use their professional judgment to advocate for what they know is best for children. Entrepreneurialism can be a wonderful asset for someone starting a business, but it has too often been problematic in too many ways for our public education system.

\section{WORKING TOWARD DEMOCRATIC PROFESSIONALISM}

Teaching and school administration as professions have been under attack for a long time and some of the criticisms have merit (Friedrich, 2014; Levine, 2006). Traditional bureaucracies and the older model of professionalism were notorious for resisting change and failing to meet the needs of many children in urban districts (Meier, 1995; Payne, 2008; Rogers, 2006). Furthermore, claims to professionalism by school personnel have often marginalized the voices of lowincome parents and communities (Driscoll, 1998; Green, 2015). The task ahead is not to merely reassert "traditional" professionalism wholesale, but rather to better understand how to resist the most egregious assaults on professionals, while acknowledging the weaknesses of traditional models of professional training and professional accountability ${ }^{2}$. Such resistance would insist on a professional ethos with democratic participation and the public good at its center.

Luckily there are alternative pathways to professionalism that do not involve de-professionalization and the elimination of academic training and certification, but rather involve building greaterprofessional and social trust and greater inclusion of those we serve, whether they are patients, students, soldiers or inmates. Democratic professionals do not yearn for a reassertion of what many view as their lost sense of status and authority. Instead, they seek to democratize their practices and their organizations. Movements in bioethics, public journalism, and restorative justice are examples of professionals seeking to regain public trust. Dzur (2008) believes that

\footnotetext{
2 By "traditional" we mean relatively recent university-based professional preparation as opposed to previous apprenticeship models.
} 
Far from a deprofessionalization or anti-institution movement, these reformers still value the specific, specialized knowledge of the seasoned journalist and editor, well-studied and practiced physician, and well-trained and experienced judge and attorney. As they try to be more democratic and help laypeople gain useful civic skills, they also seek to transform ossified conceptions of professionalism, but they are in no way anti-professional. (Dzur, 2008, p.3)

It is interesting that most reforms that attempt to improve education have been imported from business, but there are other sectors that may be more appropriate for seeking ideas. For instance, the concept of restorative justice has been imported into education from criminal justice.

\section{CONCLUSION}

Fenwick (2016) makes a distinction between professional responsibility and accountability. Professional responsibility refers to "the expectation for professionals to respond to social needs in particular ways. Accountability is about how professionals are expected to justify or account for the ways they perform those responsibilities" (Fenwick , 2016, p. 9). While professional responsibility is centered on the professional's own judgement and ethics, professional accountability is centered on professionals' compliance with externally imposed indicators of performance. As we can see, the accountability systems we have in place often pressure the "new" professional to behave irresponsibly.

The example that opened this article illustrates how teachers who opted for a more humanizing approach toward the ninth graders that they wanted to retain, were encouraged to use spreadsheets of test scores instead. While this may seem like an extreme case, it resonates with most teachers who see their responsibility as serving the whole child. Our second example of the entrepreneurial principal illustrates the extent to which market-based, incentivist policies drive principals to ignore social needs in favor of their school, their students, and their careers. Like the police officer who needs to arrest one more kid to make his constant numbers, professionals are increasingly being pushed into socially irresponsible behavior by narrow systems of accountability. Solbrekke \& Sugrue (2014) argue that the notion of professional responsibility leads to more proactive activity, while professional accountability results in more reactive behavior.

This raises the question of professional resistance to accountability measures that pressure professionals to behave "irresponsibly." How might professionals "responsibly" resist "irresponsible" accountability schemes? And how much risk are professionals willing to tolerate as they feel ethically compelled to resist irresponsible policies. Effective resistance would have to consider how 
education professionals make sense of, and negotiate, a complex ecosystem of federal and state policy, district mandates, venture philanthropy, policy networks, local advocacy groups, and market competition (Koyama, 2014). It would have to be clear about not only what and whom is being resisted, but also toward what end. It is also more effective and less risky to resist collectively than individually. There are many examples of professionals who are individually and collectively engaging proactively in what Achinstein, \& Ogawa (2006) call "principled resistance" to market-driven and prescriptive education policies. One of our future tasks as researchers is to collaborate with school teachers and leaders to document the many individual and collective ways they are resisting.

\section{REFERENCES}

Achinstein, B., \& Ogawa, R. (2006). (In) fidelity: What the resistance of new teachers reveals about professional principles and prescriptive educational policies. Harvard educational review, 76(1), 30-63.

Adamson, F., Astrad, B. Darling-Hammond, L. (2016). Global educational reform: How privatization and public investment influence education outcomes. New York: Routledge.

Anderson, G.L. \& Montoro Donchik, L. (2015) The Privatization of education and policy-making: The American Legislative Exchange Council (ALEC) and network governance in the United States. Educational Policy. Online First.

Apple, M. W., \&Jungck, S. (1992). You don't have to be a teacher to teach this unit: Teaching, technology and control in the classroom. In A. Hargreaves \& M. Fullan (Eds.), Understanding teacher development (pp. 20-42). New York: Teachers College Press.

$\mathrm{Au}, \mathrm{W}$. (2011). Teaching under the new Taylorism: high-stakes testing and the standardization of the 21 st century curriculum, Journal of Curriculum Studies, 43(1), 25-45.

Baker, B. (Sept. 9, 2017). Reality check: Trends in school finance. School Finance 101.https://schoolfinance101.wordpress.com/2017/09/09/realty-check-trendsin-school-finance/ 
Ball, S. (2001). Performativities and fabrications in the education economy: Towards the performative society. In D. Gleason \& C. Husbands (Eds.), The performing school: Managing, teaching and learning in a performance culture (pp. 210-226). London: Routledge/Falmer.

Ball, S. and Junemann, C. (2012). Networks, new governance and education. Chicago: Policy Press.

Barker, J. (1993). Tightening the iron cage: Concertive control in self-managing teams. Administrative Science Quarterly, 38(3), 408-437.

Barton, P. E., \& Coley, R. J. (2010). The Black-White Achievement Gap: When Progress Stopped. Policy Information Report. Educational Testing Service.

Beck, U. (1992) Risk Society: Towards a New Modernity. New Delhi: Sage.

Biesta, G. (2007). Why "what works" won't work: Evidence-based practice and the democratic deficit in educational research. Educational Theory, 57(1), 1-22.

Boggs, C. (2001). The End of Politics. New York: Guilford Press.

Bottery, M. (1996). The challenge to professionals from the New Public Management: Implications for the teaching profession. Oxford Review of Education, 22(2), 179-197.

Brown, E \&Makris, M.V. (2017): A different type of charterschool: in prestige charters, a rise in cachet equals a decline in access, Journal of Education Policy,DOI: 10.1080/02680939.2017.1341552

Burch, P. (2009). Hidden markets: The new education privatization. New York: Routledge.

Burch, P. (2014). Equal Scrutiny: Privatization and accountability in digital education. Cambridge, MA: Harvard Education Press.

Burris, V. (2008). The interlock structure of the policy-planning network and the right turn in U.S. state policy. Research in Political Sociology, 17, 1-35. 
Coleman, J., Campbell, E., Hobson, C. and McPartland, J. (1966). Equality of educational opportunity. Washington D.C.: U.S. Government Printing Office.

Convertina, C. (2017). State disinvestment, technologies of choice and 'fitting in': Neoliberal transformations in U.S. public education. Journal of Education Policy, 32(6),832-854.

Cohen, M. (2013). In the back of our minds always': reflexivity as resistance for the performing principal. International Journal of Leadership in Education, 1-22.

Crawford, J. (June, 6, 2007). A Diminished Vision of Civil Rights: No Child Left Behind and the growing divide in how educational equity is understood. Education Week, 26(39), 31,40.

Denhardt J. \&Denhardt, R. (2011). The new public service: Serving, nor steering. Armonk, NY: M.E. Sharpe.

DiPaola, M. \&'Tschannen-Moran, M. (2005).Bridging or buffering? The impact of schools' adaptive strategies on student achievement. The Journal of Educational Administration, 43(1), 60-71.

Driscoll, M.E. (1998). Professionalism versus Community: Is the Conflict between School and Community about to Be Resolved?. Peabody Journal of Education, 73(1), 89-127.

Evetts, J. (2009). New professionalism and New Public Management: Changes, continuities, and consequences. Comparative Sociology, 8, 247-266.

Evetts, J. (2011). A new professionalism? Challenges and opportunities. Current Sociology, 59(4), 406-422.

Exworthy, M., \&Halford, S. (1999). Professionals and the new managerialism in the public sector. Buckingham: Open University Press.

Fang, L. (Aug. 9, 2017). Sphere of influence: How American libertarians are remaking Latin American politics. The Intercept.https://theintercept. com/2017/08/09/atlas-network-alejandro-chafuen-libertarian-think-tank-latinamerica-brazil/ 
Fenwick, T. (2016). Professional responsibility and professionalism: A sociomaterial examination. New York: Routledge.

Fisher, M. (2009). Capitalist realism: Is there no alternative? Hants, UK: Zero Books.

Foster, W. (1986). Paradigms and promises: New approaches to educational administration. Buffalo: Prometheus Books.

Foucault, M. (1991) [1978]. "Governmentality", Lecture at the College de France, Feb. 1, 1978. In G. Burchell, C. Gorden\& P. Miller (Eds.) The Foucault effect: Studies in governmentality. Chicago: University of Chicago Press.

Frankenberg, E., Siegel-Hawley, G., \& Wang, J. (2011). Choice without equity: Charter school segregation. Education Policy Analysis Archives, 19 (1). http:/ epaa.asu.edu/ojs/article/view/779

Freidson, E. (2001). Professionalism: The third logic. Cambridge: Polity

Friedman, M. (1962). Capitalism and Freedom. Chicago: University of Chicago Press.

Friedrich, D. (2014). "We brought it on ourselves": University-based teacher education and the emergence of boot-camp-style routes to teacher certification. Education Policy Analysis Archives, 22(2), 21.

Gates, B. (Feb. 28, 2011). How teacher development could revolutionize our schools. Washington Post. http:/ /www.washingtonpost.com/wp-dyn/content/ article/2011/02/27/AR2011022702876.html

Gonzalez, N., Moll, L, Amanti, C. (2005). Funds of knowledge: theorizing practices in households and classrooms. Mahwah, NJ: Lawrence Erlbaum.

Green, T. (2015). Leading for urban school reform and community development. Educational Administration Quarterly, 51(5), 679-711.

Harvey, D. (2005). A brief history of neoliberalism. Oxford, UK: Oxford University Press. 
Honig, M. \& Rainey, L. (2012). Autonomy and school improvement: What do we know and where do we go from here? Educational Policy, 26(2), 465-495.

Hood, C. (1991). A public management for all seasons? Public Administration, 69, 3-19.

Jarl, M., Fredrikson, A. \&Persson, S. (2011). New public management in public education: A catalyst for the professionalization of Swedish school principals. Public Administration. 90(2), 429-444.

Keil, R. (2009). The urban politics of roll-with-it neoliberalization, City, 13(2-3), 231-245.

Kickert, W. (1995). Steering at a distance: A new paradigm of public governance in Dutch higher education. Governance, 8(1), 135-157.

Koyama, J. (2014). Principals as bricoleurs: Making sense and making do in an era of accountability. Educational Administration Quarterly, 50(2), 279-304.

Lakoff, G. (2008). The political mind: Why you can't understand 21stcentury politics with an 18th-century brain. New York: Viking.

Levine, A. (2006). Educating school teachers. Princeton, N.J.: The Education Schools Project.

Meier, D. (1995). The Power of their ideas. Boston: Beacon Press.

Meyer, H. \& Rowan, B. (2006). Institutional analysis and the study of education. In H. Meyer \& B. Rowan (Eds.). The new institutionalism in education (pp. 1-14) Albany: SUNY Press.

Milstein, M. (1990). Plateauing as an occupational phenomenon among teachers and administrators. Journal of Personnel Evaluation in Education, 3(4), 325 336.

Mungal, A.S. (2016). Teach For America, Relay Graduate School, and the charter school networks: The making of a parallel education structure. Education Policy Analysis Archives, 24(17). http://dx.doi.org/10.14507/epaa.24.2037 
Payne, C. (2008). So much reform. So little change. Cambridge, MA: Harvard.

Putnam, R. D., Frederick, C. B., \&Snellman, K. (2012). Growing class gaps in social connectedness among American youth. Cambridge, MA: Harvard Kennedy School of Government. https://sites.hks.harvard.edu/saguaro/ research/SaguaroReport_DivergingSocialConnectedness_20120808.pdf

Reardon, S. (May, 2013). The widening income achievement gap. Educational Leadership, 70(8), 10-16.

Robertson, S., Verger, A., Mundy, K., \&Menashy, F. (Eds.) (2014). Public private partnerships in education: New actors and modes of governance in a globalizing world. Cheltonham, UK: Edward Edgar Pub.

Rogers, (2006), 110 Livingston Street: Politics and bureaucracy in New York City school system. Clinton Corners, NY: Eliot Werner Pub.

Rose, N. (1993). Government, authority, and expertise in advanced liberalism. Economy and Society, 22(3), 283-300.

Sahlberg, P. (2015). Finnish lessons, 2.0: What can the world learn from educational change in Finland? New York: Teachers College Press.

Scott, J. (2009). The politics of venture philanthropy in charter school policy and advocacy. Educational Policy,23 (1), 106-136.

Scott, J. (2011). Market-driven education reform and the racial politics of advocacy. Peabody Journal of Education, 86, 580-599.

Selwyn, N. (2011). 'It's all about standardization'--Exploring the digital (re) configuration of school management and administration. Cambridge Journal of Education, 41(4), 473-488.

Sennett, R. (2006). The culture of the new capitalism. New Haven, CT: Yale University Press.

Sennett, R. (1998). The corrosion of character: The personal consequences of work in the new capitalism. New York: Norton. 
Shipps, D. (2012). Empowered or Beleaguered? Principals' Accountability Under New York City's Diverse Provider Regime. Education Policy Analysis Archives, 20(1).

Shipps, D. and White, M. (2009) A new politics of the principalship? Accountabilitydriven change in New York City. Peabody Journal of Education, 84(3), 350373.

Smith Richards, J. (2006, Oct. 22). Cheating is up - among teachers Pressure for state-test success driving some to break the rules The Columbus Dispatch, p. 4.

Solbrekke, T. \&Sugrue, C. (2014). Professional accreditation of initial teacher education programs: Teacher educators' strategies -between 'accountability' and 'responsibility', Teaching and teacher education, 37, 11-20.

Stillman, J. (2011). Teacher learning in an era of high-stakes accountability: Productive tension and critical professional practice. Teachers College Record, 113(1), 133-180.

Strathern, M. (Ed.) (2000). Audit cultures: Anthropological studies in accountability, ethics, and the academy. London: Routledge.

Taylor, M. (2006). From Pinochet to the 'third way': Neoliberalism and social transformation in Chile. London: Pluto Press.

Trujillo, T. (2014). The modern cult of efficiency: Intermediary organizations and the new scientific management. Educational Policy, 28(2), 207-232.

Valli, L. \& D. Buese. (2007). The changing roles of teachers in an era of highstakes accountability. American Educational Research Journal, 44(3), 519-558.

Verger, A., Lubienski, C. \& Steiner-Khamsi, G. (Eds.) (2016). World yearbook of education, 2016: The global education industry. London: Routledge.

Ward, S. (2011). The machinations of managerialism: New public management and the diminishing power of professionals. Journal of Cultural Economy, $4(2), 205-215$. 
Weick, K. (1976). Organizations as loosely-coupled systems. Administrative Science Quarterly. 21(1), 1-19.

Welch, A.R. (1998). The cult of efficiency in education: Comparative reflections on the reality and the rhetoric. Comparative Education, 34(2), 157-175.

GARY ANDERSON é Professor na Universidade de Nova York. E-mail: ga34@ nuy.edu 